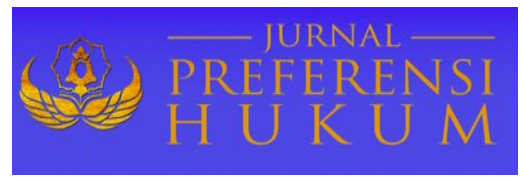

Jurnal Preferensi Hukum | ISSN: XXXX | E-ISSN: XXXX

Vol. 1 No. 1 - Juli 2020 hal. 178-183| Available online at https://www.ejournal.warmadewa.ac.id/index.php/juprehum

\title{
SANKSI PIDANA BAGI PELAKU PENYEBARAN BERITA HOAKS SERTA UJARAN KEBENCIAN DENGAN MEMAKAI AKUN ANONYM
}

\author{
I Wayan Denny Syaputra \\ Fakultas Hukum Universitas Warmadewa, Denpasar-Bali, Indonesia
}

\begin{abstract}
Abstrak
Kejahatan di dunia maya adalah kejahatan dengan teknologi komputer terutama internet. Salah satu contohnya adalah penyebaran berita bohong (hoaks) serta ujaran kebencian. Penelitian ini dilakukan untuk mengetahui pengaturan penyebaran ujaran kebencian berdasarkan hukum positif, akibat hukum yang ditimbulkan apabila seseorang terbukti meyebarkan ujaran kebencian dan menyebarkan berita bohong, dan upaya serta langkah yang diambil guna mencegah penyebaran berita hoaks dan ujaran kebencian agar tidak menyebar dimasyarakat. Penelitian ini termasuk tipe penelitian hukum normatif dengan pendekatan perundang-undangan dan pendekatan konseptual. Pengaturan penyebaran berita hoaks serta ujaran kebencian berdasarkan hukum positif telah secara tegas diatur didalam KUHP yaitu terdapat pada Pasal 154 KUHP, pasal 154a, pasal 156, pasal 156a, Serta pasal 157 ayat (1) dan ayat (2). Selain diatur didalam KUHP ujaran kebencian diatur diluar KUHP diantaranya terdapat didalam UU No.40 Tahun 2008 tentang Penghapusan Diskriminasi Ras dan Etnis yaitu terdapat pada Pasal 16, , Serta diatur juga di dalam UU No. 19 Tahun 2016 mengenai Pembaharuan atas UU No. 11 Tahun 2008 tentang ITE juga telah mengatur mengenai melakukan penyebaran ujaran kebencian melalui dunia maya yaitu yang terdapat dalam pasal 27, Pasal 28 ayat (1) serta ayat (2), pasal 40 ayat (2) dan Pasal 45 ayat (2) akibat hukum yang ditimbulkan apabila seseorang terbukti melakukan tindak pidana penyebaran berita bohong hoaks serta ujaran kebencian bisa dipenjara 2 tahun, 3 tahun bahkan hingga 10 tahun.
\end{abstract}

Kata Kunci: Berita Hoks; Ujaran Kebencian; Sanksi Pidana; Akun Anonym

\begin{abstract}
Crime in cyberspace is a crime with computer technology, especially the internet. One example is the spread of hoaxes and expressions of hatred. This research was conducted to determine the arrangements for spreading hate speech based on positive law, the legal consequences arising when someone is proven to spread hate speech and spread hoaxes, and efforts and steps taken to prevent the spread of hoax news and hate speech so as not to spread in the community. This research is a type of normative legal research with a statutory approach and conceptual approach. Arrangements for the dissemination of hoax news and expressions of hatred based on positive law have been explicitly regulated in the Criminal Code, which is found in Article 154 of the Criminal Code, Article 154a, Article 156, Article 156a, and Article 157 paragraph (1) and paragraph (2). Besides being regulated in the Criminal Code utterances of hate are regulated outside of the Criminal Code, including in Law No.40 of 2008 concerning the Elimination of Racial and Ethnic Discrimination, which is contained in Article 16, and is also regulated in Law No. 19 of 2016 concerning Renewal of Law No. 11 of 2008 concerning ITE has also regulated the distribution of hate speech through cyberspace, which is contained in article 27, article 28 paragraph (1) and paragraph (2), article 40 paragraph (2) and article 45 paragraph (2) due to the law incurred if someone is proven to have committed a crime of spreading hoax hoaxes and expressions of hatred can be jailed for 2 years, 3 years and even up to 10 years.
\end{abstract}

Keywords: Hoax News, Hate Speech, Criminal Sanctions, Anonymous Account

\section{PENDAHULUAN}

Penggunaan sosial media memiliki dampak positif dan negatif. Dampak positif penggunaan sosial media adalah semakin mudahnya informasi dapat diakses dan dibagikan, semakin luasnya jejaring yang dapat diciptakan, semakin mudahnya pembentukan komunitas-komunitas yang berdampak positif bagi masyarakat, maraknya aktifitas crowdfunding dan crowdsourcing, dan banyak dampak 
positif lainnya. Di samping dampak positif yang ditimbulkan, penggunaan internet oleh pihakpihak yang tidak beratanggung jawab (khususnya sosial media) juga dapat menimbulkan dampak negatif. Berbagai kejahatan dapat terjadi di dunia maya yang saat ini dikenal dengan istilah Kejahatan cyber.

Salah satu upaya untuk membentuk masyarakat demokratif secara lebih efektif adalah dibentuknya Undang-undang berkaitan dengan media massa dan lembaga media/penyiaran. Seringkali ditemui bahwa suatu pemerintahan berusaha membangun sistem media yang efektif untuk mendorong demokrasi tanpa memahami berbagai aspek hukum yang mempengaruhi proses dimaksud.

Perlu dipahami terlebih dahulu untuk mengidentifikasi variabel-variabel proses hukum yang memberikan kontribusi terhadap lingkungan yang memungkinkan media mendorong tercapainya tujuan yang demokratis. Di temui beberapa faktor yang menginindikasikan dimungkinkan atau tidaknya media yang bebas dan dan independen dapat berkembang. Faktor-faktor dimaksud misalnya tingkat melek huruf, kepemimpinan politik, stabilitas, dan sifat lembaga yang memungkinkan dihasilkan dan didistribusikannya informasi.

Perkembangan teknologi komunikasi dan informasi telah melahirkan masyarakat informasi yang makin besar tuntutannya akan hak untuk mengetahui dan hak untuk mendapatkan informasi. Informasi telah menjadi kebutuhan pokok bagi masyarakat dan telah menjadi komuditas penting dalam kebutuhan bermasyarakat, berbangsa, dan bernegara.

Sanksi pidana ujaran kebencian dan penyebaran berita hoax sudah banyak diteliti, salah satunya menganalisis Tindak Pidana Ujaran Kebencian (Hate Speech) Menurut Hukum Pidana Islam (Studi Kasus di Subdit V/Siber Ditreskrimsus Polda Jawa Tengah). Hasil menunjukkan bahwa penanganan tindak pidana ujaran kebencian di Ditreskrimsus Polda Jawa Tengah didasarkan pada KUHP, UU Nomor 11 Tahun 2008, UU Nomor 40 Tahun 2008, UU Nomor 7 Tahun dan Peraturan Kepala Kepolisian Negara Republik Indonesia Nomor 8 Tahun 2013 (Rudin, 2019). Analisis serupa tentang dasar pertimbangan hakim dalam penjatuhan putusan terhadap pelaku tindakan penyebaran berita hoax yang menimbulkan kebencian (studi putusan pengadilan negeri Blambangan Umpu Nomor 101/Pid.Sus/2018/PN Bbu), mengungkapkan bahwa dasar pertimbangan hakim dalam penjatuhan putusan terhadap tindak pidana penyebaran berita hoax yang menimbulkan kebencian Nomor: 101/Pid.Sus/2018. PN.Bbu adalah terpenuhinya minimal dua alat bukti dalam persidangan. Hakim juga mempertimbangkan halhal yang meringankan dari perbuatan terdakwa (Alfiah, 2020).

Berdasarkan uraian latarbelakang yang telah dijabarkan di atas, rumusan masalah penelitian ini adalah bagaimana pengaturan penyebaran berita hoaks serta ujaran kebencian berdasarkan hukum positif? Bagaimana akibat hukum yang ditimbulkan apabila seseorang terbukti melakukan tindak pidana penyebaran berita bohong (hoaks) serta ujaran kebencian? Dan apasaja upaya serta langkah yang diambil guna mencegah penyebaran berita hoaks dan ujaran kebencian agar tidak menyebar dimasyarakat? Penelitian ini dilakukan untuk mengetahui pengaturan penyebaran ujaran kebencian berdasarkan hukum positif, akibat hukum yang ditimbulkan apabila seseorang terbukti meyebarkan ujaran kebencian dan menyebarkan berita bohong, dan upaya serta langkah yang diambil guna mencegah penyebaran berita hoaks dan ujaran kebencian agar tidak menyebar dimasyarakat.

\section{METODE PENELITIAN}

Mengacu pada rumusan masalah, maka tipe penelitian yang digunakan adalah adalah penelitian normatif. Penelitian hukum normatif tentu haruslah mempergunakan pendekatan perundangundangan (statute approach), pendekatan konsep (conceptual approach), dan pendekatan kasus (Case Approach) karena yang akan diteliti adalah berbagai aturan hukum yang menjadi fokus dan merupakan tema sentral suatu penelitian sekaligus tema suatu penelitian, dan pendekatan penelitian yang menunjuk pada pada hal-hal umum atau objek-objek yang menarik perhatian dari sudut pandang praktis dan sudut pandang ilmu pengetahuan dalam hal ini ilmu hukum.

Dalam penelitian ini sumber bahan hukum yang dipergunakan yaitu bahan hukum primer, bahan hukum sekunder, dan bahan hukum tersier. Adapun yang termasuk bahan hukum primer yaitu: UUD NRI 1945, UU No 1 tahun 1946 tentang Kitab Undang Undang Hukum Pidana, UU No 19 Tahun 2016 Tentang Perubahan Atas UU No. 11 Tahun 2008 Tentang Informasi Dan 
Transaksi Elektronik (ITE), UU No.40 Tahun 2008 tentang Penghapusan Diskriminasi Ras dan Etnis, serta peraturan lainnya yg mempunyai korelasi dengan masalah yang akan dipecahkan dalam penelitian ini. Sumber bahan hukum sekunder diambil dari literatur, buku-buku hukum, jurnal karya ilmiah yang membahas tentang permasalahan yang ada di dalam penelitian ini, serta sumber bahan hukum tersier adalah bahan hukum yang didapat dari penelusuran internet atau website yang bisa digunakan untuk mencari atau memecahkan masalah di dalam penelitian ini.

Teknik pengumpulan bahan hukum yang digunakan di dalam penelitian ini yaitu studi dokumen atau juga yang biasa disebut sebagai teknik pengumpulan bahan hukum yang dilihat dari undang-undang dan peraturan perundang-undangan selain undang undang yang terkait dengan permasalahan yangada dalam penelitian, teknik pengumpulan bahan hukum kepustakaan yang mempulkan bahan dengan cara mengambil pada literatur, buku-buku, dan juga karya ilmiah yang berkaitan dengan penelitian, dan juga studi intrnet yaitu teknik pengumpulan bahan hukum dari internet atau sosial media yang mempunyai kaitan dengan penelitian yang akan diteliti.

Metode yang pergunakan dalam pengolahan maupun di dalam analisis bahan hukum digunakan dalam penulisan penelitian ini adalah deskriptif. Di dalam penelitian hukum normatif, biasanya dipergunakan bahan hukum sekunder yaitu literatur-literatur, catatan perkuliahan, peraturan perundang- undangan, teori-teori hukum dan pendapat dari para sarjana hukum terdahulu sehingga akan memuaskan kesimpulan.

\section{HASIL DAN PEMBAHASAN}

Pengaturan penyebaran berita hoaks serta ujaran kebencian berdasarkan hukum positif Alexander Tseis menyebut ujaran kebencian yang meliputi penghinaan, pencemaran nama baik, penistaan, perbuatan tidak menyenangkan, memprovokasi, menghasut, dan penyebaran berita bohong sebagai sesat informasi yang disebarkan dalam bentuk orasi kampanye, spanduk, jejaring media sosial, penyampaian pendapat di muka umum, ceramah keagamaan, media massa cetak maupun elektronik, sampai pamflet dengan tujuan utama mempersekusi kelompok minoritas yang ditarget (Mahyuddin, 2019).

Kepala Biro Penerangan Masyarakat Divisi Humas Polri Brigjen Rikwanto, menerangkan orang yang menebarkan berita palsu atau hoaks di internet akan dikenakan hukuman berdasarkan aturan yang berlaku, hukum positif adalah hukum yang aktif di negara republik Indonesia (Muludi, 2018).

Perkembangan teknologi yang terjadi memberikan dampak positif serta dampak negatif, dan untuk mencegah dampak negatif yang akan terjadi akibat dari perkembangan teknologi, Indonesia perlu membuat atau merancang aturan yang mengatur mengenai teknologi informasi khususnya larangan mengenai ujaran kebencian serta penyebaran berita hoaks karena bila kita melihat KUHP pasal 1 ayat 1 menyatakan bahwa suatu perbuatan tidak dapat dipidana, kecuali berdasarkan kekuatan ketentuan perundang-undanganpidana yang telah ada.

Pengaturan mengenai penyebaran ujaran kebencian dan penyebaran berita bohong (hoaks) bila ditinjau dari hukum positif yaitu diatur di dalam serta diluar kitab undang-undang hukum pidana (KUHP) didalam KUHP,bagi pelaku penebar berita hoaks dan ujaran kebencian akan dikenakan (KUHP) yakni Pasal 154 KUHP, pasal 154a, pasal 156, pasal 156a, Serta pasal 157 ayt (1) dan ayt (2).

Entah berkat kesimpulan perbuatannya terlarang yang sama tetapi objeknya berbeda, maupun karena sejarahnya yang tidak "menguntungkan" kehadiran pasal tersebut, Perumusan tindakannya yang terlarang ialah "menyatakan perasaan permusuhan, kebencian dan peremehan. Objek yang dimaksud yaitu terdapat pada Pasal 154 dan pasal 154a adalah Pemerintah, Sedangkan pada Pasal 156 serta pasal 156a adalah rakyat.

Pasal tersebut dikenal sebagai "pasal penaburan kebencian" (Haatzaai-artikelen), yang paling dihindari oleh orang yang mengharapkan keadilan atau paling tidak oleh mereka yang hendak meluruskan sesuatu yang dipandang menyimpang. Berikut ini uraian dari pasal-pasal didalam KUHP yang mengatur mengenai ujaran kebencian dan berita bohong (hoaks)

Pasal 154 KUHP yang menyebutkan "Barang siapa di muka umum menyatakan perasaan permusuhan, kebencian atau penghinaan terhadap Pemerintah Indonesia, diancam dengan pidana penjara paling lama tujuh tahun atau pidana denda paling banyak empat ribu lima ratus rupiah.” 
Pasal 154a menyebutkan "Barang siapa menodai bendera kebangsaan Republik Indonesia dan lambang negara Republik Indonesia, dihukum dengan hukuman penjara selama - lamanya empat tahun atau denda setinggi - tingginya tiga ribu rupiah."

Pasal 156 KUHP yang menyebutkan"Barang siapa di muka umum menyatakan perasaan permusuhan, kebencian, atau penghinaan terhadap suatu atau beberapa golongan rakyat Indonesia, diancam dengan pidana penjara paling lama empat tahun atau pidana denda paling banyak empat ribu lima ratus rupiah." pasal 157 KUHP:

1. "Barang siapa menyiarkan, mempertunjukkan atau menempelkan tulisan atau lukisan di muka umum, yang isinya mengandung pernyataan perasaan permusuhan, kebencian atau penghinaan diantara atau terhadap golongan-golongan rakyat Indonesia, dengan maksud supaya isinya diketahui atau lebih diketahui oleh umum, diancam dengan pidana penjara paling lama dua tahun enam bulan atau pidana denda paling banyak empat rupiah lima ratus rupiah."

2. "Jika yang bersalah melakukan kejahatan itu dalam jabatanya dan pada waktu melakukan kejahatan itu belum lagi lewat lima tahun sejak putusan hukumannya yang dahulu lantaran kejahatan serupa itu juga telah mendapat ketetapan, maka dapat ia dipecat dari jabatannya."

Selain pasal-pasal yang terdapat didalam KUHP diatas pengaturan mengenai penyebaran berita hoaks dan ujaran kebencian diatur juga didalam UU No. 1 Tahun 1946 mengenai Peraturan Hukum Pidana yg terdapat pada pasal 14 ayat 1 dan ayt (2) serta juga terdapat pada pasal 15 yang mengatur mengenai ujaran kebencian dan berita hoaks

Selain diatur didalam KUHP atauran mengenai ujaran kebencian juga diatur diluar KUHP Selain diatur juga didalam KUHP atauran mengenai perkataan yg tidak menyenangkan juga diatur diluar KUHP diantaranya terdapat didalam UU No. 40 Th 2008 mengenai Penghapusan Diskriminasi Ras dan Etnis yaitu terdapat pada Pasal 16, yaitu untuk di klausulkan, Serta diatur juga di dalam UU No. 19 Th 2016 mengenai Pembaharuan dari UU No. 11 Tahun 2008 mengenai ITE yg telah mengatur mengenai melakukan penyebaran ujaran kebencian melalui media sosial yaitu yang terdapat pada pasal 27, Pasal 28 ayat (1) serta ayat (2), pasal 40 ayat (2) dan Pasal 45 ayat (2).

Jika menggunakan pasal 14 dan 15 UU no. 1 tahun 1946, maka tidak diperlukan klausul lain, karena ia murni memberikan kabar palsu serta ujaran kebencian, sang pelaku tindak pidana penyebaran berita berita hoaks dapat dikenakan sanksi pidana 2 tahun, 3 tahun bahkan 10 tahun.

Sanksi pidana juga diterapkan khusus di jajaran ASN, yaitu mengenai penyebaran berita hoaks yg mengandung perkataan yg tidk pantas, jenis sanksi hukuman yg akan diterapkan kepada pelaku ASN ini meliputi sanksi ringan dan sanksi berat sebagaimana diatur dlm pasal 7 PP No. 53 Tahun 2010 mengenai Disiplin Pegawai Negeri Sipil.

Tidak hanya sekadar oknum ASN yang membagikan berita hoaks bernada kebencian, bahkan ASN yang menunjukan pendapat dengan melakukan like, dislike atau berpendapat pada postingan yang bernada kebencian tersebut juga dapat dikenakan hukuman ringan.

\section{Akibat Hukum Yang Ditimbulkan Apabila Seseorang Terbukti Melakukan Tindak Pidana Penyebaran Berita Bohong (Hoaks) Serta Ujaran Kebencian}

Peristiwa pidana yang juga disebut tindak pidana (delict) ialah tindakan atau berbagai tindakan yg bisa diberi hukuman pidana, sebagai peristiwa pidana jika memenuhi faktor-faktor pidananya yg terbagi dari faktor obyektif yaitu tindakan (perbuatan) yg tidak sesuai dengan hukum serta faktor subjektif yaitu perbuatan yg bertentangan dengan aturan atau undang-undang (Prasetyo, 2012).

Adapun penarapan hukuman pidana yg ada dalam UU No. 1 Tahun 1946 tentang KUHP yaitu pasal 14 dan/atau 15 dapat dicermati dari contoh kasus dibawah ini. Kasus Penyebaran Berita Bohong (Hoaks) Serta Ujaran Kebencian bila di cermati didalam KUHP/UU no. 1 Tahun 1946 mengenai KUHP yg terdapat pada pasal 14 ayat 1 dan ayat 2 serta juga terdapat pada pasal 15 yaitu ancaman pidana penjara serendah-rendahnya dua tahun dan maksimal pidana penjara selama sepuluh tahun seperti yang menimpa pelaku penyebar berita hoaks Ratna sarumpaed.

Selain kasus dari ratna sarumpaet masih terdapat kasus saracen: Pesan kebencian dan hoaks di media sosial pada hari rabu (23/8), Kepolisian Indonesia mengungkapkan penangkapan tiga pimpinan sindikat Saracen yang diduga berada di balik sejumlah berita bohong dan provokatif bernuansa SARA di media sosial. 
Penerapan sanksi pidana dari UU No 19 Tahun 2016 mengenai pembaharuan Atas UU No. 11 Tahun 2008 mengenai ITE dapat dicermati juga dari contoh kasus dibawah ini.

Polisi juga menyampaikan dari hasil investigasi forensik digital, terungkap kelompok ini memanfaatkan grup Facebook-antara lain Saracen News, Saracen Cyber Team, serta Saracennews.com untuk berikutnya pelaku mengunggah konten provokatif bernuansa SARA dengan mengikuti perkembangan tren di jagad maya.

Caranya, kelompok yg melakukan aksinya dari November 2015 tersebut mengirimkan proposal kepada beberapa pihak, setelah itu kelompok tersebut menjual jasa mengumumkan perkataan kebencian mengandung SARA di jagad maya. Tiga tersangka yg ditangkap yakni MFT, 43, yang berperan membidangi media dan informasi situs Saracennews.com, SRN, 32, yang berperan sebagai koordinator grup wilayah, dan JAS, 32, yang berperan sebagai ketua.

Dari tersangka JAS, polisi menahan barang bukti 50 kartu sim berbagai operator, 5 hardisk CPU dan 1 harddisk komputer jinjing, 4 ponsel, 5 flashdisk, serta 2 kartu memori. Sedangkan dari dua tersangka lain didapat antara lain ponsel, kartu memori, flash disk, komputer jinjing, dan harddisk.

Terhadap dua tersangka, yakni MFT dan SRN, disangkakan Pasal 45 A ayat 2 jo pasal 28 ayat (2) UU no 19 tahun 2016 mengenai perubahan UU ITE dengan pidana kurungan 6 tahun penjara dan atau pasal 45 ayat (3) jo pasal 27 ayat (3) UU ITE dengan pidana kurungan 4 tahun penjara. Sedangkan kepada pemimpin kelompok dijerat tindak pidana akses ilegal Pasal 46 ayat (2) jo pasal 30 ayat (2) dan atau pasal 46 ayat (1) jo pasal 30 ayat (1) UU ITE no 11 tahun 2008 dengan pidana kurungan 7 tahun penjara.

\section{Upaya serta langkah yang diambil guna mencegah penyebaran berita hoaks dan ujaran kebencian agar tidak menyebar di masyarakat}

Dalam melawan hoaks dan mencegah meluasnya dampak negatif hoaks Berbagai cara telah dilakukan baik oleh pemerintah maupun masyarakat yang peduli terhadap maraknya hoaks di kehidupan masyarakat, pemerintah telah membuat payung hukum yang memadai guna mencegah meluasnya dampak negatif dari berita hoaks yaitu dengan terbentuknya norma yg mengatur mengenai hal tersebut serta memblok alamat situs yang menyebarkan hoaks dan menangkap kelompok penyebar hoaks hingga membentuk organisasi siberkrasi yg berfoksus dlm memberantas hoaks (Aditiawarman, 2009).

Aparat penegak hukum memiliki tanggung jawab untuk menegakkan aturan-aturan yang telah ada serta berlaku selain itu aparat penegak juga memiliki tanggungjawab untuk mensosialisaikan aturan-aturan tersebut kepada masyarakat agar masyarakat dapat lebih berhatihati didalam menanggapi suatu berita serta, agar masyarakat mencari tau kebenaran dari sebuah berita sebelum mempercayainya dan menyebarluaskannya.

Selain pemerintah dan aparat penegak hukum masyarakat terutama generasi muda juga memiliki tanggungjawab untuk ikut berperan aktif membantu pemerintah dalam menanggulangi dampak negatif dari meluasnya penyebaran berita hoaks.

Beberapa kelompok masyarakat dengan suka rela bergabung kedalam kelompok maupun komunitas, seperti masyarakat anti fitnah indonesia (mafindo), dan forum anti fitnah, hasut dan hoaks (FAFHH). Kedua kelompok tersebut sebagai kelompok penekan dan pengontrol hoaks secara virtual.

Masyarakat harus dapat menanggapi segala sesuatunya dengan bijak, cermat, serta lebih berhati-hati saat menerima ataupun menyebarluaskan suatu informasi agar masyarakat tidak mudah terpengaruh dengan berita-berita yang belum pasti kebenarannya.

Beberapa langkah yang dapat dilakukan masyarakat dalam menanggulangi dampak negatif dari penyebaran berita hoaks adalah setiap menerima informasi perlu melakukan pengecekan terhadap pembuat berita, tidak disarankan untuk membagikan tautan yang berisi berita sensasional,bila informasi terkait dengan isu-isu yang memicu emosi disarankan untuk berhatihati, melacak berita dengan aplikasi di media sosial seperti FB, twitter, dan sebagainya (Simarmatama, Iqbal, Hasibuan, Limbong, \& Wahyuddinalbra, 2019).

\section{SIMPULAN DAN SARAN}

\section{Simpulan}


Berdasarkan uraian di atas, dapat disimpulkan bahwa pengaturan Penyebaran berita hoaks serta Ujaran Kebencian Berdasarkan Hukum Positif diatur pada KUHP pasal 154 KUHP, pasal 154a, pasal 156, pasal 156 a, Serta pasal 157 ayat (1) dan ayat (2), dalam UU No. 40 Tahun 2008 mengenai Penghapusan Diskriminasi Ras dan Etnis terdapat pada Pasal 16, di dalam UU No. 19 Tahun 2016 mengenai Pembaharuan dari UU No. 11 Tahun 2008 mengenai ITE juga telah diatur mengenai penyebaran ujaran kebencian melalui media sosial yang terdapat pada pasal 27, Pasal 28 ayat (1) serta ayat (2), pasal 40 ayat (2) dan Pasal 45 ayat (2).

Akibat Hukum Yang ditimbulkan apabila seseorang terbukti melakukan tindak pidana penyebaran berita bohong (hoaks) serta ujaran kebencian bila di cermati didalam KUHP/UU No.1 Tahun 1946 yaitu ancaman pidana serendah-rendahnya 2 tahun dan maksimal pidana penjara selama 10 tahun. Selain itu terdapat juga aturan pada UU No 19 Tahun 2016 pembaharuan atas UU No. 11 Tahun 2008 tentang ITE yang terdapat pada pasal 27, Pasal 28 ayat (1) serta ayat (2), pasal 40 ayat (2) dan Pasal 45 ayat (2) serta UU No.40 Tahun 2008 dengan sanksi pidana empat tahun hingga tujuh tahun penjara.

Upaya serta langkah yang diambil guna mencegah penyebaran berita hoaks dan ujaran kebencian agar tidak menyebar dimasyarakat yaitu dengan membentuknya norma yg mengatur mengenai hal itu serta memblok alamat situs yang menyebarkan hoaks dan menangkap kelompok penyebar hoaks.

\section{Saran}

Berdasarkan simpulan di atas, berbagai saran positif disampaikan diantaranya bagi pemerintah sebaiknya memberikan sosialisasi yang berupa penyuluhan memalui media masa ataupun media sosial kepada masyarakat khususnya para generesi muda yang aktif dimedia soaial mengenai aturan-aturan yang berlaku.

Bagi penegak hukum agar lebih tegas didalam menindak para pelaku yang melakukan kejahatan dibidang informasi transaksi dan elektronik khususnya dalam tindak pidana penyebaran berita palsu (hoaks) dan ujaran kebencian serta memberi informasi mengenai apa yang dimaksud dengan hal tersebut.

Bagi masyarakat sebaiknya harus lebih bijak didalam menerima informasi berita agar tidak mudah terpengaruh oleh informasi berita yang belum pasti kebenarannya serta mencari tau kebenaran dari informasi berita tersebut sebelum menyebarluaskan.

\section{DAFTAR PUSTAKA}

Aditiawarman, M. (2009). Hoax dan hate speech didunia maya. lembaga kajian aset budaya indonesia tonggak tuo.

Alfiah, Y. P. N. (2020). Analisis Dasar Pertimbangan Hakim Dalam Penjatuhan Putusan Terhadap Pelaku Tindakan Penyebaran Berita Hoax Yang Menimbulkan Kebencian (Studi Putusan Pengadilan Negeri Blambangan Umpu Nomor 101/Pid.Sus/2018/PN Bbu) (Universitas Lampung Bandar). Retrieved from http://digilib.unila.ac.id/61391/3/skripsi tanpa bab pembahasan.pdf

Mahyuddin. (2019). Sosiologi komunikasi Dinamika relasi sosial didalam Era Virtualitas. Makasar: Penerbit shovia - CV. Loe.

Muludi, S. (2018). Awas Hoaks Cerdas Menghadapi Pencemaran Nama Baik, Ujaran Kebencian \& Hoaks. Jakarta: PT. Alex Media Kompurindo.

Prasetyo, T. (2012). Hukum Pidana. Jakarta: Rajagrafindo Persada.

Rudin, M. I. (2019). Analisis Terhadap Tindak Pidana Ujaran Kebencian (Hate Speech) Menurut Hukum Pidana Islam (Studi Kasus di Subdit V/Siber Ditreskrimsus Polda Jawa Tengah) (Universitas Islam Negeri Walisongo). Retrieved from http://eprints.walisongo.ac.id/10726/1/1402026066.pdf

Simarmatama, J., Iqbal, M., Hasibuan, M. S., Limbong, T., \& Wahyuddinalbra. (2019). Hoaks Dan Media Sosial Saring Sebelum Sharing. Yayasan kita menulis. 